\title{
Numerical Simulations of Hurricane Bertha Using a Mesoscale Atmospheric Model
}

by

R. L. Buckley

Westinghouse Savannah River Company

Savannah River Site

Aiken, South Carolina 29808

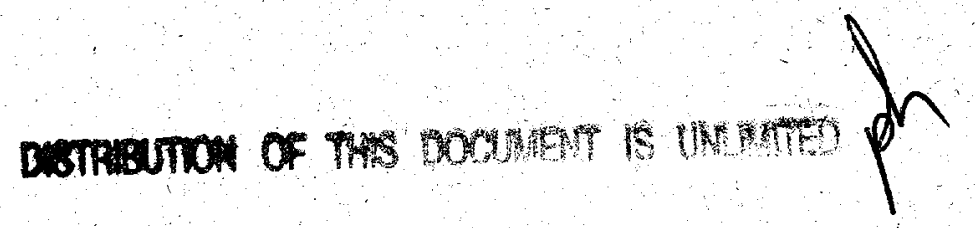

DOE Contract No. DE-AC09-89SR 18035

This paper was prepared in connection with work done under the above contract number with the U.S.

Department of Energy. By acceptance of this paper, the publisher and/or recipient acknowledges the U. S. Government's right to retain a nonexclusive, royalty-free license in and to any copyright covering this paper, along with the right to reproduce and to authorize others to reproduce all or part of the copyrighted paper. 


\section{DISCLAIMER}

This report was prepared as an account of work sponsored by an agency of the United States Government. Neither the United States Government nor any agency thereof, nor any of their employees, makes any warranty, express or implied, or assumes any legal liability or responsibility for the accuracy, completeness, or usefulness of any information, apparatus, product, or process disclosed, or represents that its use would not infringe privately owned rights. Reference herein to any specific commercial product, process, or service by trade name, trademark, manufacturer, or otherwise does not necessarily constitute or imply its endorsement, recommendation, or favoring by the United States Government or any agency thereof. The views and opinions of authors expressed herein do not necessarily state or reflect those of the United States Government or any agency thereof.

This report has been reproduced directly from the best available copy.

Available to DOE and DOE contractors from the Office of Scientific and Technical Information, P.O. Box 62, Oak Ridge, TN 37831; prices available from (615) 576-8401.

Available to the public from the National Technical Information Service, U.S. Department of Commerce; 5285 Port Royal Road, Springfield, VA 22161. 


\section{DISCLAMMER}

Portions of this document may be illegible in electronic image products. Images are produced from the best available original document. 


\section{NUMERICAL SIMULATIONS OF HURRICANE BERTHA USING A MESOSCALE ATMOSPHERIC MODEL (U)}

Robert L. Buckley

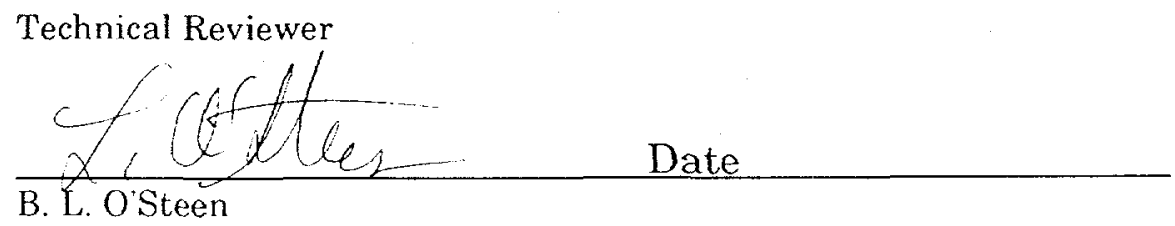

Approval
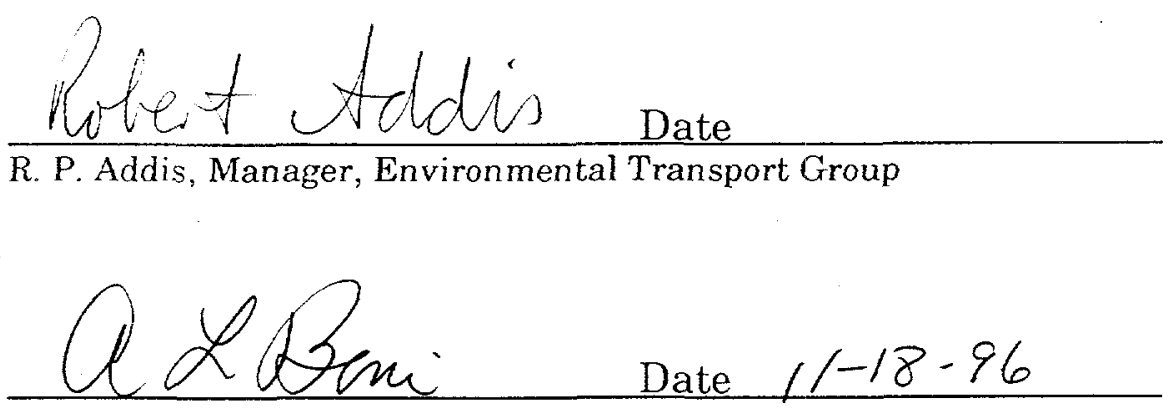

A. L. Boni, Manager, Environmental Technology Section

August 1996

Westinghouse Savannah River Company

Savannah River Site

Aiken, SC 29808

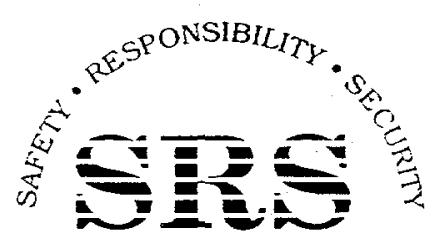

SAVANNAH RIVER SITE

PREPARED FOR THE U.S. DEPARTMENT OF ENERGY UNDER CONTRACT NO. DE-AC09-89SR18035 
Retention: Lifetime

\title{
NUMERICAL SIMULATIONS OF HURRICANE BERTHA USING A MESOSCALE ATMOSPHERIC MODEL (U)
}

\author{
Robert L. Buckley
}

Issued: August 1996 


\title{
NUMERICAL SIMULATIONS OF HURRICANE BERTHA USING A MESOSCALE ATMOSPHERIC MODEL (U)
}

\author{
By Robert L. Buckley \\ Westinghouse Savannah River Company \\ Savannah River Site \\ Aiken, SC 29808
}

\section{EXECUTIVE SUMMARY}

The Regional Atmospheric Modeling System (RAMS) has been used to simulate Hurricane Bertha as it moved toward and onto shore during the period July 10-12, 1996. Using large-scale atmospheric data from 00 UTC, 11 July (Wednesday evening) to initialize the model, a 36-hour simulation was created for a domain centered over the Atlantic Ocean east of the Florida coast near Jacksonville. The simulated onshore impact time of the hurricane was much earlier than observed (due to the use of results from the large-scale model, which predicted early arrival). However, the movement of the hurricane center (eye) as it approached the North Carolina/South Carolina coast as simulated in RAMS was quite good. Observations revealed a northerly storm track off the South Carolina coast as it moved toward land. As it approached landfall, Hurricane Bertha turned to the north-northeast, roughly paralleling the North Carolina coast before moving inland near Wilmington. Large-scale model forecasts were unable to detect this change in advance and predicted landfall near Myrtle Beach, South Carolina; RAMS, however, correctly predicted the parallel coastal movement.

For future hurricane activity in the southeast, RAMS is being configured to run in an operational mode using input from the large-scale pressure data in hopes of providing more information on predicted hurricane movement and landfall location.

\subsection{INTRODUCTION}

Onshore movement of hurricanes in the southeastern United States is always a possibility during the summer and autumn (i.e. the "hurricane season"). For the 30 year period spanning 1946 to 1976, the North Atlantic experienced an annual average of 10 tropical storms, with a maximum in frequency during September ${ }^{1}$. The destructive force of hurricanes includes wind 
damage, storm surge, inland freshwater flooding, as well as the spawning of inland tornadoes ${ }^{2}$. Prevention of injury and fatalities along heavily populated coastlines has vastly improved with forecast models generated and used by the National Weather Service. However, the horizontal and vertical resolution of such models is coarse and may not capture many local features, such as the land/sea interaction. The use of a mesoscale numerical model with finer vertical and horizontal resolution may aid the meteorologist in predictions of hurricane movement.

This brief report discusses work done by the Environmental Technology Section's Environmental Transport Group in operating an advanced numerical mesoscale model, RAMS, to simulate Hurricane Bertha as it moved along the Atlantic coast in mid-July, 1996.

\subsection{MODEL INPUT}

The Regional Atmospheric Modeling System (RAMS), developed at Colorado State University ${ }^{3}$, is a three-dimensional, primitive equation finite-difference model, containing many physical parameterizations of surface-air interactions, which can be used to study a variety of atmospheric motions (ranging in size from global down to large eddy). Since the model domain contains no true lateral boundary conditions, the numerical results of largescale hemispheric models are required to set the time-dependent constraints along the domain boundaries 4 .

The National Meteorological Center (NMC) provides a variety of objective weather analyses and forecast products on a regular basis 5 . This application uses the aviation analysis and forecast system, commonly referred to as the aviation model. This model contains a 72 -hour forecast on a horizontal grid encompassing the northern hemisphere with $190 \mathrm{~km}$ spacing and 13 vertical levels from the surface up to $20 \mathrm{mbar}(\sim 25000 \mathrm{~m})$. Various meteorological quantities, such as winds, temperature, and moisture content are assigned to the large-scale grid points using observations from many sources including radiosondes, buoys, aircraft, satellites, and land/sea surface observations. This procedure is performed twice daily at 00 UTC and 12 UTC, corresponding to $8 \mathrm{PM}$ and $8 \mathrm{AM}$ local time. Forecasts of meteorological data on this coarse grid at 6 -hour intervals are also available.

The domain used in RAMS for this study is centered east of the Florida coast $\left(80^{\circ} \mathrm{W}\right.$ longitude, $31^{\circ} \mathrm{N}$ latitude) near Jacksonville and extends westward to Mississippi, north to West Virginia and south to Cuba $(1800 \mathrm{~km} \mathrm{x} 1800 \mathrm{~km})$ and has a horizontal spacing of $30 \mathrm{~km}$. The vertical grid is terrain-following 
and stretches from $100 \mathrm{~m}$ at the surface to roughly $1 \mathrm{~km}$ at the model top $(18000 \mathrm{~m})$.

Large-scale aviation model data from 00 UTC, 11 July 1996 (8 PM, 10 July local time) was used and model simulations were begun at this time. The center of Hurricane Bertha was located east of Palm Beach, Florida $\left(77^{\circ} \mathrm{W}\right.$, $27^{\circ} \mathrm{N}$ ) and predicted to track northward. Forecasts of the aviation model at 6hour intervals were also used by the model during a 36 -hour simulation (ending at 8 AM, 12 July). The total simulation time (on the Cray J916) was roughly 9 hours.

\subsection{RESULTS}

Figure 1 illustrates the time-dependent location of the hurricane eye as observed and simulated using the large-scale aviation model and RAMS. The time interval between observations is three hours, except after landfall, when 2 -hour intervals are used. The time interval between RAMS markers is 3 hours, while large-scale model results are given in 6-hour increments. Actual landfall transpired at $\sim 20$ UTC, July 12 (2 PM), while the models predict this to occur 12 hours earlier.

The large-scale aviation model predicted the storm center to move to the north-northwest and to make landfall near Myrtle Beach, South Carolina by 2 AM, 12 July before moving over land to the north-northeast. Note that strong westerlies in the upper atmosphere actually sheared the top of Hurricane Bertha during the day on 11 July, which slowed inland advance by 12 hours; this was not predicted by the large-scale model, thus timing of landfall in RAMS is incorrect as well.

In contrast to the large-scale predictions, RAMS predicted the storm to veer to the north-northeast before entering into North Carolina near Wilmington. Although the timing of landfall is in error, the trajectory is closer to reality. Finer grid resolution in RAMS, as well as more realistic surface flux parameterizations of heat, moisture, and momentum are believed to account for the deflection of the storm trajectory to the north-northeast not seen in large-scale results.

The circulation created by the hurricane is illustrated in RAMS by examining wind flow (streamlines) at a model level $5000 \mathrm{~m}$ above ground (Fig. 2). (Images were created using Interactive Data Language (IDL) software). Vertical motion generated in RAMS at the same level (shaded contour surfaces) indicates the presence of strong convective bands emanating out 
from the eye and circulating counterclockwise, with the strongest upward movement along the seaward side of the storm as it paralleled the North Carolina coast. Isosurfaces of cloud water generated by the model (Fig. 3) reveal a typical mushroom shaped surface which spins counterclockwise in the lower parts of the hurricane, while moving clockwise and outward from the top at roughly $10000 \mathrm{~m}$. Convective activity observed over central Florida during the afternoon of 11 July was also predicted by the model.

Thus, the RAMS mesoscale model is capable of simulating the basic features of the hurricane for the domain chosen in this study. In addition, its finer resolution allows more accurate simulations of the interaction of hurricane circulations with the coast, which is not always possible with large-scale hemispheric models.

\subsection{CONCLUSIONS}

Techniques developed in the Environmental Transport Group allow for an automated forecast of hurricane movement using RAMS. Since the largescale data are not currently available until 6 hours after the observing time (i.e. 06 UTC and 18 UTC), forecasts using RAMS in real time would have to begin at this time. Use of the J916 Cray would allow for a 24-hour forecast in roughly 5 hours (beginning at 06 UTC or 18 UTC), or a 48-hour forecast in 9 hours, which includes generating the initial conditions, running the RAMS model, and creating graphical output (using NCAR). For example, using large-scale data which is valid at $8 \mathrm{PM}$ local time, a 24-hour forecast beginning at 2 AM ( 6 hours later) could be automatically generated, with graphical output by $7 \mathrm{AM}$, or 48 -hour forecasts by roughly $11 \mathrm{AM}$ the following morning. Such information could prove useful to local meteorologists in predicting the impact hurricanes may have along the southeastern coast of the United States. 


\subsection{REFERENCES}

1. Kotsch, W. J. and R. Henderson (1984): Heavy Weather Guide, Second Edition. Naval Institute Press, 399 pp.

2. Lutkens, F. K. and E. J. Tarbuck (1989): The Atmosphere. An Introduction to Meteorology, Fourth Edition: Prentice Hall, $491 \mathrm{pp}$.

3. Pielke R. A., W. R. Cotton, R. L. Walko, C. J. Tremback, W. A. Lyons, L. D. Grasso, M. E. Nicholls, M. D. Moran, D. A. Wesley, T. J. Lee, and J. H. Copeland (1992): A comprehensive meteorological modeling system-RAMS. Meteor. Atmos. Phys., 49, 69-91.

4. O'Steen, B. L. and J. D. Fast (1992): Mesoscale atmospheric modeling of accidental toxic and radioactive releases for emergency response at SRS. WSRC-RP-92-868, Savannah River Site, Aiken, SC 29808.

5. Sela, J. G. (1982): The NMC Spectral Model. NOAA Technical Report NWS 30. U. S. Department of Commerce, NOAA, Silver Spring, MD. 


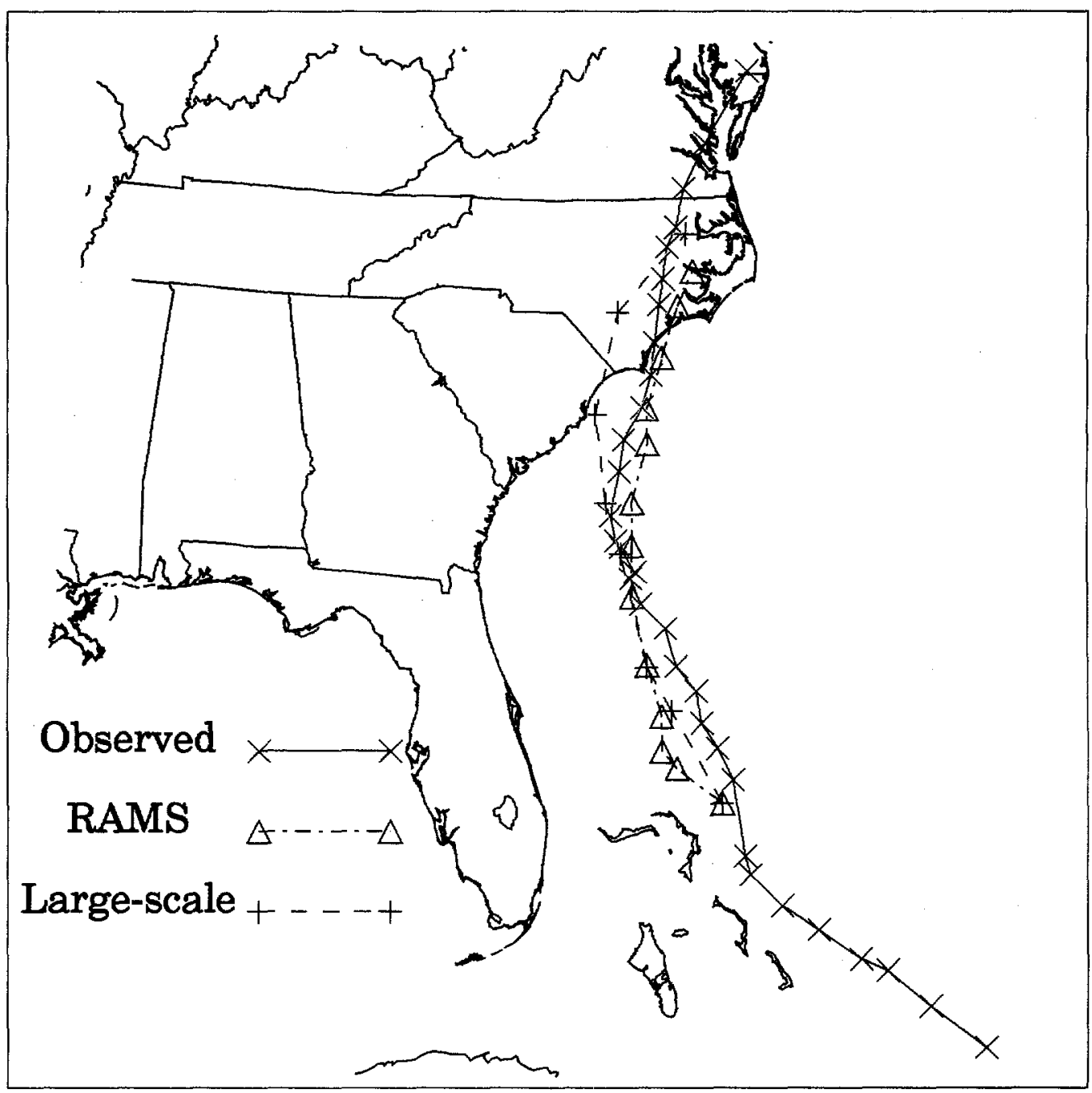

Figure 1: Movement of Hurricane Bertha. Observed markers begin at 00 UTC, 10 July in the southeast corner and continue in 3-hour increments until over land, when 2-hour increments are used. RAMS and large-scale model simulation markers begin at 00 UTC, 11 July, east of the Florida coast. RAMS markers are separated by 3 hours, while large-scale markers differ by 6 hours. 


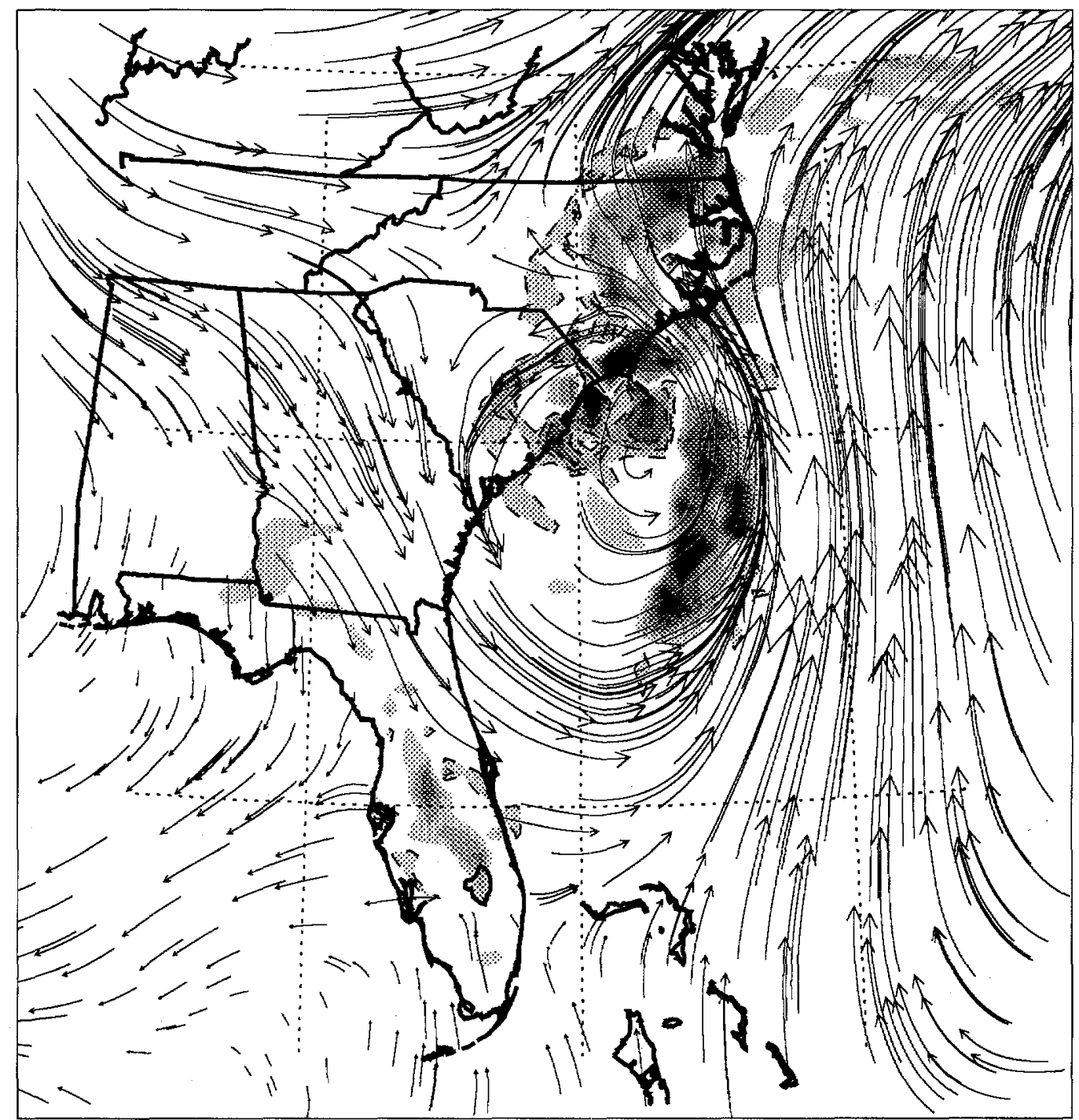

Figure 2: RAMS generated wind fields (streamlines) at 20:00 EDT, 11 July 1996 at model level $5100 \mathrm{~m}$ above ground level. Shaded areas indicate vertical velocity at this level in $10(\mathrm{~cm} / \mathrm{s})$ increments (darker implies more intense). Downward motion is denoted by areas surrounded by dashed lines. 


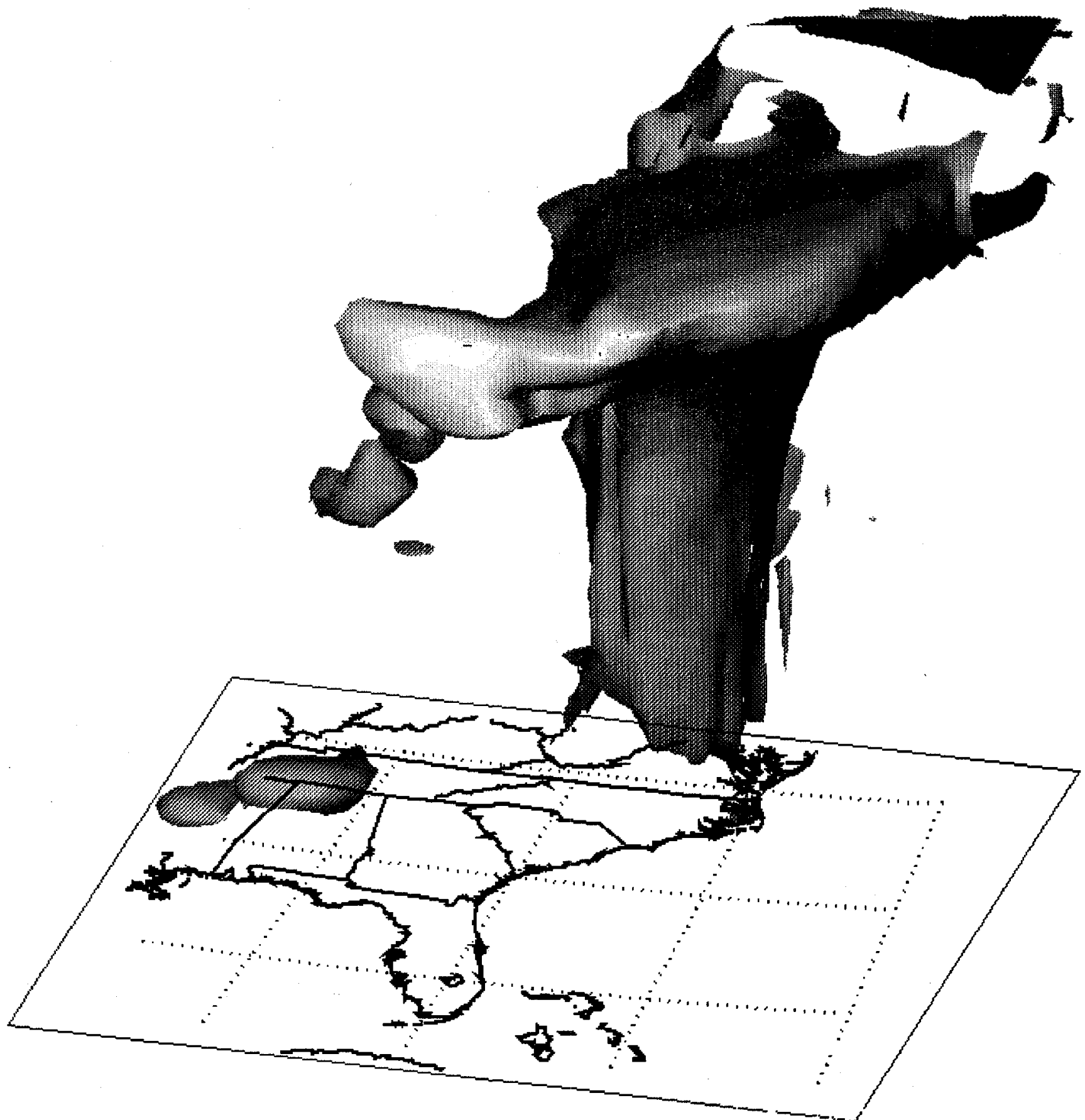

Figure 3: RAMS generated cloud water isosurface $(0.5 \mathrm{~g} / \mathbf{k g})$ at 06:00 EDT, 12 July 1996 as viewed from the south-southeast. Vertical gcale stretched with cloud tops at roughly $10000 \mathrm{~m}$ above ground. 


\section{NUMERICAL SIMULATIONS OF HURRICANE BERTHA USING A MESOSCALE ATMOSPHERIC MODEL (U)}

\section{DISTRIBUTION}

P. Deason, 773-A

L. M. Papouchado, 773-A

A. L. Boni, 773-A

R. P. Addis, 773-A

W. H. Carlton, 773-A

W. A. Emel, 735-A

A. J. Garrett, 773-A

J. E. Halverson, 735-A

K.F. Chen, 773-A

D. P. Griggs, 773-A

C. H. Hunter, 773-A

R. J. Kurzeja, 773-A

B. L. O'Steen, 773-A

M. J. Parker, 735-7-A

J. Stewart, 773-A

A. H. Weber, 773-A

R. L. Buckley, 773-A

J. Arnett, 703-47A

C. Edwards, 703-47A

E. C. Goodson, 703-47A

J. Merrick, 703-47A

G. Whitney, 703-47A

R. E. DeBusk, 706-8C

M. Dukes, 742A

SRTC Records(4), 773-52A

ETG Records(5), 773-A 